\section{THE CASE OF DR. DEFRIEZ.}

\author{
To the Editor of THE LANCE'T.
}

SIR, - Will you kindly allow me to state that I shall be happy to receive subscriptions from local practitioners on behalf of $\mathrm{Dr}$. Defriez, whose case was mentioned at the last meeting of the Society of Dnion Medical Officers.

I am, Sir, your obedient servant,

WM. WOODWARD, M.D.,

Worcester, May sth, 1871. Local Secretary for Worcestershire.

\section{IRELAND.}

(FROM OUR SPECIAL CORRESPONDENT.)

\section{MEDICAL SUPERANNUATION ACT.}

AT a late meeting of the guardians of Tipperary Union, Dr. Bradshaw, late medical officer, was allowed $£ 50$ per annum superannuation, being equal to one-half of his former salary. Dr. Bradshaw served faithfully as a dispensary medical officer for twenty-two years, and it was an ungenerous act to refuse him the sum he asked for-viz., twothirds of his salary. Indeed, some of the guardians, Lord Lismore among others, did not consider he was entitled to any retiring allowance. It is to be hoped that a modification of the present Superannuation Act will shortly take place, rendering it compulsory and not voluntary on the part of the guardians to give what every Poor-law medical officer is entitled to after a long service, and when incapacitated from old age or illness to perform his duties.

THE LATE MAURICE H. COLLIS.

A marble bust of this gentleman, who lost his life some time past by a wound received during an operation, has been placed in the hall of the Meath Hospital, to which institution he was for many years attached. The bust has been executed by Mr. Watlins, of this city, and is considered to be an admirable likeness.

\section{ROYAL COLLEGE OF SURGEONS.}

At a meeting of the College held on the 2nd inst., the following gentlemen were elected:-Examiners of Letters Testimonial and Fellowship: John Barker, Christopher Fleming, Benjamin Wills Richardson, M. Harry Stapleton, Edward A. Stoker, Joliffe T. Tufnell, Edward Stamer O'Grady. Examiners in Midwifery: John Cronin, John R. Kirkpatrick, William Roe. Examiners in General Eductution: Thomas Byrne, John Murray, and Edmund Nugent.

\section{ROYAI MEDICAL BENEVOLENT FUND SOCIETY OF IRELAND.}

The annual distribution of the funds at the disposal of this society will take place on the first Monday in June next, when it is to be hoped that the subscriptions for the past year will allow the directors of the society the opportunity of enlarging the number of those already receiving assistance.

The quarterly meeting of the committee of the Belfast Branch took place in Belfast on the 3rd inst., the chair being occupied by the permanent president, Dr. T. $H$. Purdon. The largeness and influential character of the meeting evidenced the increasing interest taken on behalf of a society whose objects are so truly benevolent, and so deserving of the best support, not only of the members of our profession, but of the public also, and which, I am happy to be able to say, it is experiencing in fair measure. The principal business of this meeting was the consideration of applications for grants at the ensuing annual meeting, to be held in Dublin on the 5th of June next. A letter was'read from one of the Dublin honorary secretaries, requesting as early a statement as possible of the proceedings and subscriptions for the past year, in order that the Central Committee might be prepared with their report for the general meeting next month; and accordingly the secretary was instructed to supply the information requested. In connexion with the annual meeting of the parent society in Dublin, Dr. T. H. Purdon, and Dr. Browne, R.N., ex-mayor, were appointed to attend it as a deputation from the branch, after which the members separated.
VIENNA.

(FROM OUR OWN CORRESPONDENT.)

EXPERTMENTS WITH REGARD TO THE TRANSPLANTATION OF SKIN.

Dr. Hormort, assistant in the surgical clinique of Professor Dumreicher, has recently had under his care a young woman, aged twenty-seven years, with a varicose ulcer, three inches long and two and a half inches wide, on the left leg, a little above the ankle. She came under treatment on the 30th January last, and continued from that date until the 6th of February to have bandages moistened with a solution of caustic potash (one grain to the ounce of water) applied, but the ulcer did not beal, although its surface became covered with granulations. On the 6th of February a patient with caries of the bones of the wrist had his hand amputated. He was a man of twenty years of age, and healthy with the exception of this wrist-joint. Eight minutes after the amputation, Dr. Hof mokl took up a fold of skin from the back of the amputated hand with forceps, and then with scissnrs cut out a piece of about the size of half a square inch. He then wiped the ulcer on the foot of the woman with lint, placed on it the piece of skin, and laid over that a small plate of wood, which he finally fixed with lint and plaster. The dressing was carefully changed at the end of twenty-four hours, and the transplanted skin was found already adherent to the ulcer, and with its natural colour unaltered. The ulcer was bound up again as at first, and a similar dressing repeated daily, only sponging the wound each time with tepid water. On the fourth day the surface of the new skin had a more chalky white colour than before, but held fast to the parts beneath. On the seventh day the epidermis on both edges of the flap detached itself from the flap in very transparent minute scales, and beneath appeared the papillæ as rose-red bodies. Only a strip of epidermis, about haif a line broad in the middle of the flap, remained unshed. With the erception of this loss of epidermis, the whole flap remained firmly attached to the ulcer, and appeared, in reference to the remaining surface of the wound, as a beautiful island of skin projecting about half a line above it.

During more than ten days after this small independent centres of skin formation appeared in this small strip of epidermis and in the whole fap of skin itself, but a more active production of new skin did not begin before the fourteenth day of this latter period. The edges of the flap then began to blend imperceptibly with the granulating surface of the ulcer, while a new and tolerably rapid cicatrisation went on from the little epidermis strip.

The dressing applied consisted during the first four days of the plate of wood above mentioned; after that time sticking-plaster only was used, with a simple ointment of one grain of nitrate of silver to one ounce of lard, to prevent the plaster adhering to the skin-flap and so irritating it.

On March 11th the ulcer was entirely cicatrised, and by close examination the contour of the transplanted skin-flap could be still clearly distinguished. The cicatrix resembled any other fresh scar, except that part of the new skin-flap was decidedly firmer and more able to resist pressure than the tissues in its immediate neighbourhood.

Another transplantation experiment has been made by Dr. Czerny, assistant at the General Hospital. He placed a piece of epithelium from a freshly extirpated nasal polypus on the surface of a granulating wound, and found that the epithelium became united to the surface of the skin without losing its ciliated character. He has succeeded also in transplanting the skin of a lizard on to a frog, but has failed in effecting a similar transplantation of skin from animals of different species higher in the scale on to one another. However, still more recently a young Russian physician, in Professor Stricker's laboratory, has obtained union between a small piece of skin (not epithelium only) cut with scissors from his own thigh and a wound in the neck of a dog. On the seventh day the transplanted skin appeared on the red granulating surface as a white patch, of the size of half the cut surface of a split pea, and was entirely adherent to its new situation. On the tenth day 